Vol 1. No. 3, Juli 2021 P-ISSN : 2774-8014, e-ISSN : 2774-7034

\title{
PENINGKATAN HASIL BELAJAR SISWA DALAM MENGENAL MALAIKAT DAN TUGASNYA MELALUI METODE MAKE A MATCH DENGAN MENGGUNAKAN KARTU SOAL DI KELAS 1V SEMESTER GENAP SDN 029 BALIKPAPAN TENGAH TAHUN PELAJARAN 2019/2020
}

\author{
MUTHMAINNAH \\ SD Negeri 029 Balikpapan Tengah, Balikpapan, Kalimantan Timur \\ Email: muthmainnah023@gmail.com
}

\begin{abstract}
ABSTRAK
Model pembelajaran kooperatif terdapat beberapa macam teknik, salah satu teknik tersebut adalah menggunakan kartu soal siswa diajak untuk belajar sambil bermain, dengan cara saling menjodohkan kartu yang dimilikinya sehingga pembelajaran Agama Islam menjadi lebih menarik dan siswa dapat menyukai pembelajaran Agama Islam dan dapat dengan mudah memahami isi materi di sampaikan oleh guru sehingga hasil belajar siswa akan meningkat.Penelitian ini merupakan Penelitian Tindakan Kelas (PTK) bertujuan untuk mengetahui dampak penggunaan metode make a match terhadap hasil belajar siswa dalam mengenal malaikat dan tugasnya di Kelas IV SDN 029 Balikpapan Tengah Tahun pelajaran 2019/2020, Materi dalam penelitian ini adalah Mengenal Malaikat dan Tugasnya menggunakan Metode Make a Match Penelitian ini dilaksanakan sebanyak dua siklus setiap siklus 2 kali pertemuan. Subyek penelitian ini adalah siswa kelas IV berjumlah 20 siswa dan obyek penelitian ini adalah penggunaan Metode Make a Match. Teknik pengumpulan data yang digunakan adalah teknik dokumentasi untuk mengetahui nilai dasar dan pengelompokan siswa, observasi untuk mengetahui aktivitas siswa dan guru, teknik tes untuk mengetahui nilai rata-rata dan ketuntasan belajar siswa.Penelitian dilakukan sebanyak dua siklus, siklus I sebanyak 2 kali pertemuan dengan 1 kali tes di akhir pertemuan, dan siklus II terdiri dari 2 kali pertemuan dengan 1 kali tes di akhir pertemuan, teknik analisis data menggunakan statistik deskriptif berupa rata-rata, presentase dan grafik. Yang bertindak sebagai pelaksana dalam pembelajaran adalah peneliti sekaligus menjadi obsevator.Hasil analisis data menunjukkan bahwa Peningkatan tersebut dapat dilihat pada setiap siklusnya, yaitu nilai rata-rata sebelum tindakan perbaikan pembelajaran dengan dengan rata-rata 66,29 meningkat menjadi 76,15 pada siklus I dan pada siklus II meningkat menjadi 78,75 sedangkan peningkatan ketuntasan belajar siswa mengalami peningkatan secara signifikan yaitu ketuntasan sebelum adanya tindakan perbaikan pembelajaran yaitu siswa yang tuntas siswa yang tuntas hanya 38,10\% meningkat menjadi $75 \%$ pada siklus I kemudian pada siklus II meningkat menjadi $90 \%$.
\end{abstract}

Kata Kunci : Model Pembelajaran, Metode Make A Match, Penelitian Tindakan Kelas

\section{PENDAHULUAN}

Pendidikan merupakan usaha agar manusia dapat mengembangkan potensi dirinya melalui proses pembelajaran. Sesuai dengan Undang-undang Guru dan Dosen No.20 tahun 2003 tentang Sistem Pendidikan Nasional Pasal 3 yang menyatakan bahwa: Pendidikan bertujuan untuk mengembangkan potensi peserta didik agar menjadi manusia yang beriman dan bertaqwa kepada Tuhan Yang Maha Esa, berakhlak mulia, sehat, berilmu, cakap, kreatif, mandiri, dan menjadi warga Negara yang demokratis serta bertanggung jawab. Dalam prakteknya pembelajaran Agama Islam yang terjadi di sekolah-sekolah saat ini lebih menekankan pada metode mengajar secara informatif yaitu guru menjelaskan atau ceramah dan siswa mendengarkan atau mencatat. Metode ceramah merupakan metode yang boleh dikatakan metode tradisional, karena sejak dulu metode ini telah dipergunakan sebagai alat komunikasi lisan antara guru dan siswa dalam proses belajar mengajar 1 (Syaiful Bahri Djamarah : 2006). 
Pembelajaran dengan metode ceramah merupakan yang paling disenangi oleh guru karena metode ini paling mudah dilaksanakan. Komunikasi yang terjadi dalam proses ini umumnya satu arah yaitu dari guru kepada siswa sehingga pembelajaran terpusat pada apa yang disampaikan oleh guru (teacher centered).

Penerapan model pembelajaran yang bervariasi sangat berpengaruh terhadap hasil belajar siswa karena dengan menggunakan model pembelajaran. Pusat pembelajaran bukan lagi terletak pada guru melainkan pusat pembelajaran pada siswa. Siswa bukan lagi sebagai objek dalam pembelajaran namun sebagai subjek pembelajaran. Model pembelajaran yang dapat diterapkan oleh seorang guru dalam melatih peserta didik dalam berkomunikasi dan berinteraksi sosial dengan temannya untuk mencapai tujuan pembelajaran. Dengan model pembelajaran guru akan dapat mengembangkan keterampilan intelektual, sosial, dan personal siswa. Leo Sutrisno (2008) mengemukakan "hasil belajar merupakan gambaran tingkat penguasaan siswa terhadap sasaran belajar pada topik bahasan yang didemonstrasikan, yang diukur dengan berdasarkan jumlah skor jawaban benar pada soal yang disusun sesuai dengan sasaran belajar". Zuhairini, dkk (1983) menyatakan "hasil belajar dapat dijelaskan dengan memahami dua kata yang membentuknya, yaitu "hasil" dan "belajar".Pengertian hasil menunjuk kepada suatu perolehan akibat dilakukannya suatuaktivitas yang mengakibatnya berubahnya input secara fungsional". Suharsimi Arikunto (2003) " hasil belajar adalah hasil akhir setelah mengalami proses belajar, dimana tingkah laku itu tampak dalam bentuk perubahan yang dapat diamati dan diukur ". Hamalik Oemar (2002) menjelaskan bahwa hasil belajar merupakan perubahan tingkah laku siswa setelah mengikuti rangkaian pembelajaran atau pelatihan.

Berdasarkan berbagai pendapat di atas dapat disimpulkan bahwa hasil belajar adalah tingkat pengetahuan yang dicapai siswa terhadap materi yang diterima ketika mengikuti dan mengerjakan tugas dan kegiatan pembelajaran di sekolah. Pembelajaran yang melibatkan siswa akan menjadikan pembelajaran lebih bermakna sehingga diharapkan materi dapat tersampaikan dengan maksimal.Berdasarkan latar belakang yang telah diuraikan di atas, maka ada beberapa masalah yang ada yaitu' Pembelajaran Agama Islam masih berjalan monoton ,Belum ditemukan strategi belajar yang tepat, Rendahnya hasil belajar siswa di Kelas IV SDN 029 Balikpapan Tengah ,maka penulis menentukan rumusan masalahnya adalah : " Apakah dengan menerapkan metode Make a match dapat meningkatkan hasil belajar siswa dalam mengenal malaikat dan tugasnya di Kelas IV SDN 029 Balikpapan Tengah Tahun pelajaran 2019/2020". Yang tujuannya adalah untuk mengetahui dampak penggunaan metode make a match terhadap hasil belajar siswa dalam mengenal malaikat dan tugasnya di Kelas IV SDN 029 Balikpapan Tengah Tahun pelajaran 2019/2020.

Adapun manfaat dari penelitian ini adalah : Siswa akan lebih mudah dalam memahami materi yang disampaikan oleh guru, serta menimbulkan minat belajar peserta didik., guru lebih termotivasi untuk terus belajar serta membekali diri dengan berbagai aspek keilmuan yang berkenaan dengan aspek kependidikan. Bagi lembaga pendidikan atau sekolah, dapat meningkatkan mutu pendidikan dan tercapainya standar kelulusan.

\section{METODE PENELITIAN}

Subjek penelitian adalah siswa kelas IV SDN 029 Balikpapan Tengah yang berjumlah 20 orang. Sedangkan yang menjadi objek penelitian adalah Pelajaran Pendidikan Agama Islam dengan Make a match menggunakan kartu soal. Penelitian ini dilaksanakan pada semester Genap Tahun Pembelajaran 2019/2020. Tempat penelitian adalah di SDN 029 Balikpapan Tengah dikelas IV yang beralamat dijalan Marthadinata RT 15 No 66 Kelurahan Mekar Sari Kota 
Balikpapan. Depdiknas, (2004) Adapun rancangan (desain) PTK yang digunakan dalam penelitian ini adalah menggunakan model Kemmis dan McTaggart, Pelaksanaan tindakan dalam PTK meliputi empat alur (langkah): (1) perencanaan tindakan; (2) pelaksanaan tindakan; (3) Pengamatan; (4) refleksi. Alur (langkah) pelaksanaan tindakan yang dimaksud dapat dilihat pada gambar berikut.

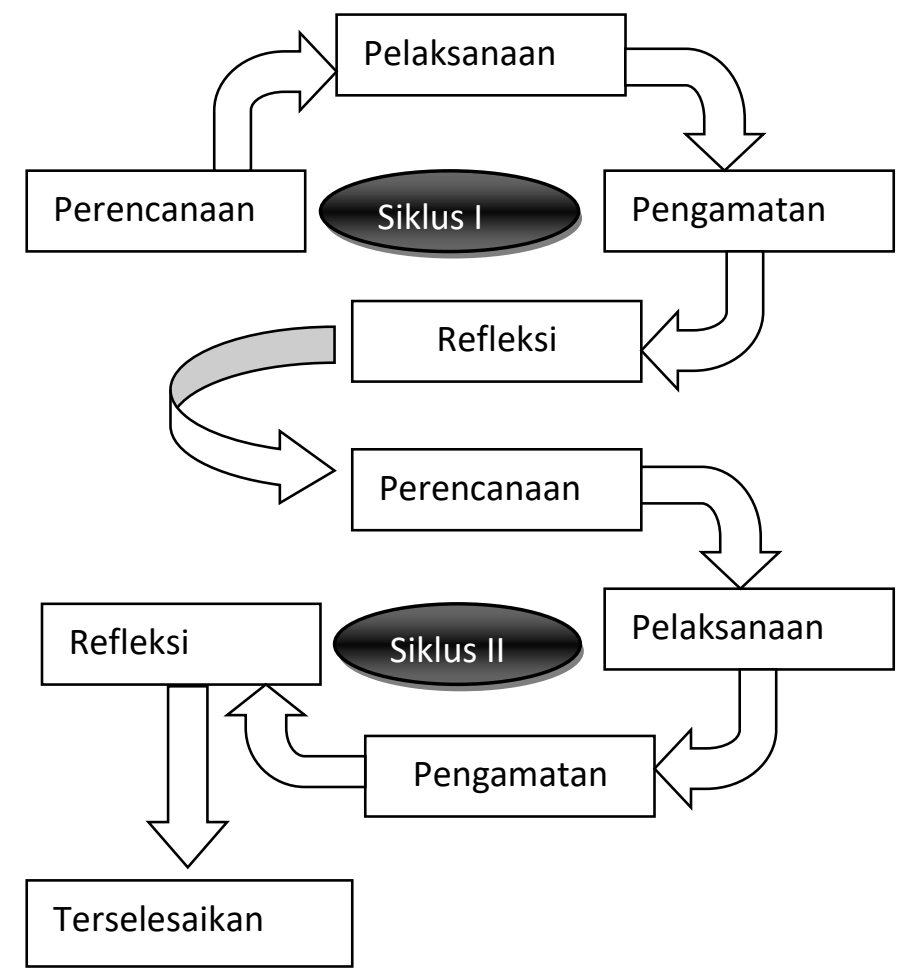

Gambar 1. Alur Penelitian Tindakan Kelas

Gambar tersebut di atas menunjukkan bahwa pertama, sebelum melaksanakan tindakan, terlebih dahulu peneliti merencanakan secara seksama jenis tindakan yang akan dilakukan. Kedua, setelah rencana disusun secara matang, barulah tindakan itu dilakukan. Ketiga, bersamaan dengan dilaksanakan tindakan, peneliti mengamati proses pelaksanaan tindakan itu sendiri dan akibat yang ditimbulkannya. Keempat, berdasarkan hasil pengamatan tersebut, peneliti kemudian melakukan refleksi atas tindakan yang telah dilakukan. Jika hasil refleksi menunjukkan perlunya dilakukan perbaikan atas tindakan yang telah dilakukan, maka rencana tindakan perlu disempurnakan lagi agar tindakan yang dilaksanakan berikutnya tidak sekedar mengulang apa yang telah diperbuat sebelumnya. Demikian seterusnya sampai masalah yang diteliti dapat mengalami kemajuan dengan melakukan perbaikan baik dari segi metode ataupun aktivitas pembelajaran yang meliputi aktivitas guru dan siswa.

\section{HASIL DAN PEMBAHASAN}

Penelitian ini dilaksanakan di SDN 029 Balikpapan Tengah yang terletak di Jalan Marthadinata RT 15 No. 66 Kelurahan Mekar Sari Kecamatan Balikpapan Tengah Kota Balikpapan. Siswa yang dikenakan tindakan adalah siswa Kelas IV yang berjumlah 20 orang. Penelitian ini dilaksanakan pada semester 2 Tahun pembelajaran 2019/2020 sesuai dengan jadwal 
Pelajaran PAI di kelas IV SDN 029 Balikpapan Tengah. Jenis penelitian adalah penelitian tindakan kelas yang dilakukan dalam 2 siklus.

Pada Siklus I dimulai dengan tahapan perencanaan adapun yang dilaksanakan adalah peneliti membuat rencana persiapan pembelajaran, media pembelajaran, media kartu dan gambar, lembar kerja siswa dan lembar pengamatan siswa yang sesuai dengan materi pembelajaran, materi yang disajikan pada rencana pelaksanaan pembelajaran pada lampiran. Kata media berasal dari bahasa latin yaitu jamak dari kata medium yang secara harfiah berarti perantara atau pengantar. Media adalah segala sesuatu yang dapat menyalurkan informasi dari sumber kepada penerima (Hairudin : 2008). Sadiman dalam (Musfiqon : 2004) mengatakan, media adalah perantara atau pengantar pesan dari pengirim ke penerima pesan.

Tabel 1. Nilai Tes Siswa Siklus I

\begin{tabular}{|c|c|c|c|c|c|}
\hline \multirow[b]{2}{*}{ No } & \multirow[b]{2}{*}{ Nama Siswa } & \multirow[b]{2}{*}{ KKM } & \multirow[b]{2}{*}{ Nilai } & \multicolumn{2}{|c|}{ Keterangan } \\
\hline & & & & Tuntas & $\begin{array}{c}\text { Tidak } \\
\text { Tuntas } \\
\end{array}$ \\
\hline 1 & Aulia Nurlina & 78 & 85 & Tuntas & \\
\hline 2 & Arfiana Dewi & 78 & 80 & Tuntas & \\
\hline 3 & Abigail Imam W & 78 & 78 & Tuntas & \\
\hline 4 & Ezha Artha N & 78 & 78 & Tuntas & \\
\hline 5 & Fidyah Mauriani & 78 & 80 & Tuntas & \\
\hline 6 & Fahlita Mulyanti & 78 & 78 & Tuntas & \\
\hline 7 & Iqbal Eka Satria & 78 & 80 & Tuntas & \\
\hline 8 & Karin Ramadhani & 78 & 60 & & Tidak Tuntas \\
\hline 9 & Kirana A & 78 & 80 & Tuntas & \\
\hline 10 & Saiban & 78 & 80 & Tuntas & \\
\hline 11 & Nur Huda & 78 & 80 & Tuntas & \\
\hline 12 & M. Ridho & 78 & 80 & Tuntas & \\
\hline 13 & Nazwa Salsabilah & 78 & 65 & & Tidak Tuntas \\
\hline 14 & Tegar & 78 & 80 & Tuntas & \\
\hline 15 & Nur Fadilah & 78 & 65 & & Tidak Tuntas \\
\hline 16 & Nikita & 78 & 82 & & \\
\hline 17 & Putri Firda & 78 & 65 & Tuntas & Tidak Tuntas \\
\hline 18 & Reksa Satya & 78 & 80 & Tuntas & \\
\hline 19 & Rizky Aqila & 78 & 82 & Tuntas & \\
\hline 20 & Ridho Ahmad & 78 & 65 & & Tidak Tuntas \\
\hline & Jumlah & & 1497 & 15 & 5 \\
\hline & Rata-rata & & 76,15 & & \\
\hline & Prosentase Ketuntasan (\%) & & & 75 & 25 \\
\hline & $\begin{array}{l}\text { Nilai Tertinggi } \\
\end{array}$ & & 85 & & \\
\hline & Nilai Terendah & & 65 & & \\
\hline
\end{tabular}


Vol 1. No. 3, Juli 2021 P-ISSN : 2774-8014, e-ISSN : 2774-7034

\begin{tabular}{|c|c|c|c|}
\hline \multirow{2}{*}{ No } & \multirow{2}{*}{ Nama Siswa } & \multicolumn{2}{|c|}{ Nilai } \\
\hline & & Pra siklus & Siklus I \\
\hline 1 & Aulia Nurlina & 80 & 85 \\
\hline 2 & Arfiana Dewi & 75 & 80 \\
\hline 3 & Abigail Imam W & 65 & 78 \\
\hline 4 & Ezha Artha N & 65 & 78 \\
\hline 5 & Fidyah Mauriani & 65 & 80 \\
\hline 6 & Fahlita Mulyanti & 72 & 78 \\
\hline 7 & Iqbal Eka Satria & 70 & 80 \\
\hline 8 & Karin Ramadhani & 55 & 60 \\
\hline 9 & Kirana A & 65 & 80 \\
\hline 10 & Saiban & 65 & 80 \\
\hline 11 & Nur Huda & 70 & 80 \\
\hline 12 & M. Ridho & 65 & 80 \\
\hline 13 & Nazwa Salsabilah & 60 & 65 \\
\hline 14 & Tegar & 65 & 80 \\
\hline 15 & Nur Fadilah & 60 & 65 \\
\hline 16 & Nikita & 75 & 82 \\
\hline 17 & Putri Firda & 60 & 65 \\
\hline 18 & Reksa Satya & 65 & 80 \\
\hline 19 & Rizky Aqila & 70 & 82 \\
\hline 20 & Ridho Ahmad & 50 & 65 \\
\hline & Jumlah & 1392 & 1497 \\
\hline & Rata-rata & 66,29 & 76,15 \\
\hline & Prosentase Ketuntasan (\%) & 38,10 & 75 \\
\hline & Nilai Tertinggi & 80 & 85 \\
\hline & Nilai Terendah & 55 & 65 \\
\hline
\end{tabular}

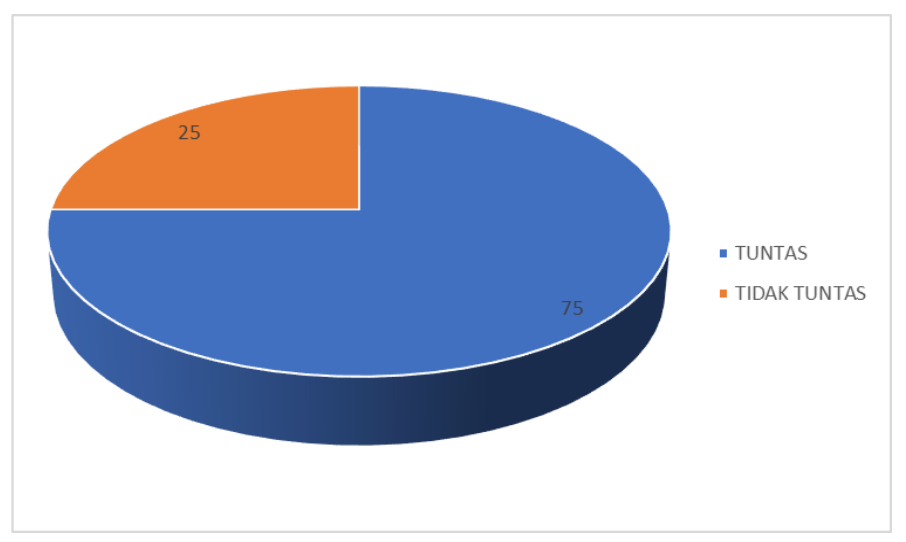

\section{Gambar 2. Porsentase Ketuntasan Belajar Siswa Siklus I}

Setelah dilaksanakan perbaikan pembelajaran pada siklus 1 selesai maka dapat diketahui adanya kenaikan hasil belajar siswa dari perolehan nilai sebelum dilakukan pembelajaran Make $a$ match dengan kartu soal 
Dari hasi nilai pra siklus, masih banyak siswa yang nilainya belum mencapai Kriteria Ketuntasan Minimal, KKM yang ditargetkan adalah 78. Dari 20 orang siswa terdapat 8 orang siswa yang nilainya mencapai KKM, jika dipersentasikan jumlah siswa yang nilainya mencapai KKM adalah 38,10 \%. Setelah diadakan perbaikan pembelajaran pada siklus 1, ternyata ada terjadi peningkatan ketuntasan belajar pada siklus I menjadi $76,15 \%$ siswa yang tuntas maka kenaikan persentase dari nilai pra siklus ke siklus 1 yaitu 38,09 \%. Ini membuktikan ada peningkatan nilai siswa antar nilai pra siklus dan Siklus1.

Dalam tahap ini peneliti bersama teman sejawat menilai keberhasilan tindakan pembelajaran terhadap guru dan siswa pada siklus I. Mengevaluasi tahap-tahap kegiatan melakukan aktivitas terhadap hasil-hasil yang telah dicapai. Hasil refleksi ini selanjutnya digunakan oleh peneliti bersama teman sejawat sebagai dasar bagi upaya perbaikan pembelajaran pada siklus II diteruskan dengan mengulangi tahapan yang benar. Pengumpulan data dilaksanakan oleh peneliti yang sekaligus guru kelas bersama teman sejawat guru sebagai pengamat selama proses perbaikan pembelajaran. Untuk mengetahui tingkat keberhasilan penggunaan Make a match dengan kartu soal yang digunakan pada siklus I maka dilakukan perbandingan hasil tes siklus I dan nilai pra siklus yang nantinya dapat dipergunakan untuk melaksanakan tindakan perbaikan pada siklus selanjutnya.

Pada siklus I hasil belajar siswa dengan rata-rata 76,15 dengan nilai tertinggi 85 dan nilai terendah 65. Berdasarkan tabel 1 ketuntasan belajar siswa pada siklus I dapat digambarkan pada grafik sebagai berikut:

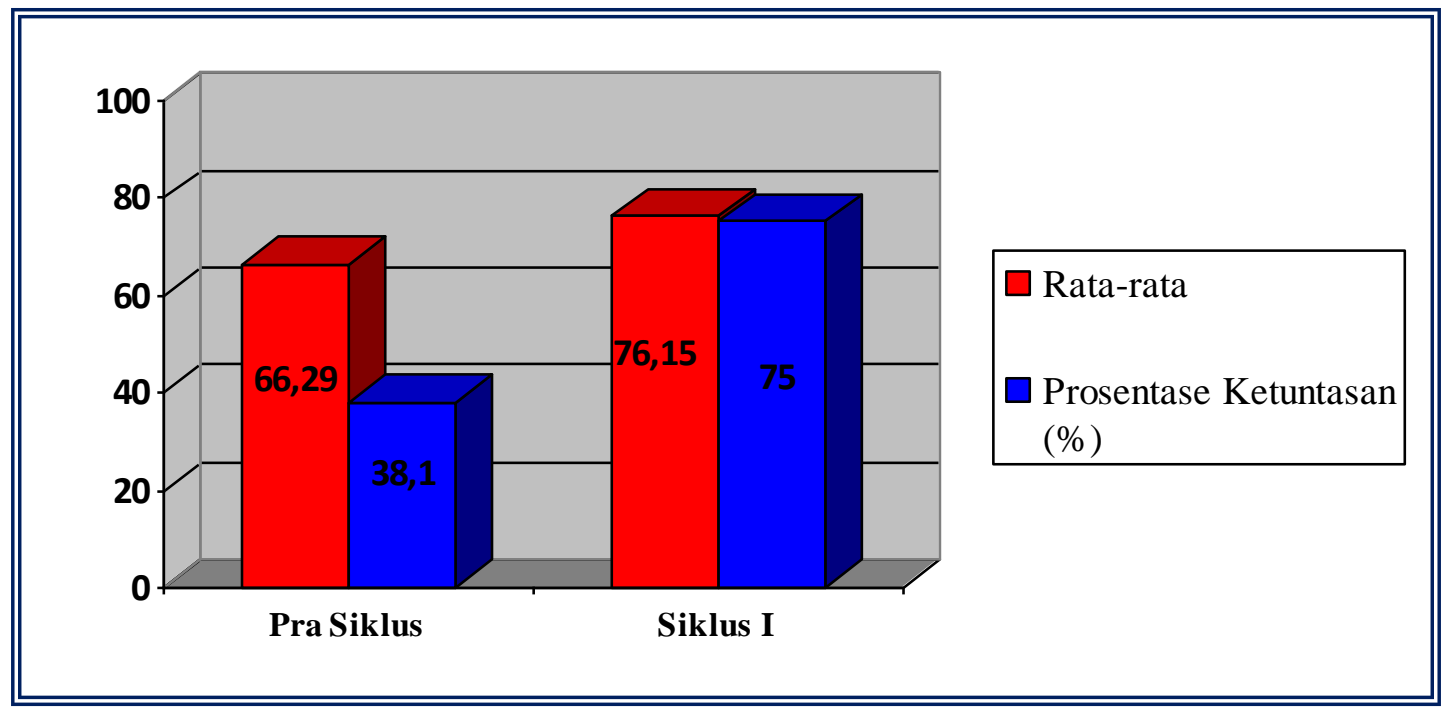

\section{Gambar 2.Grafik Perbandingan Perolehan Nilai Siswa Dasar Dan Siklus I Pelaksanaan kegiatan siklus II}

Peneliti berusaha menyempurnakan cara mengajar dengan Make a match dengan kartu soal berdasarkan hasil refleksi Siklus I. Berdasarkan hasil refleksi siklus satu, maka tindakan tambahan yang direncanakan pada siklus dua ini adalah: arahan kembali tentang langkahlangkah pelaksanan Make a match dengan kartu soal kepada siswa, diinformasikan topik pelajaran yang akan dating pada pertemuan berikutnya dengan tujuan agar siswa lebih siap lagi melakukan kegiatan pembelajaran dan pelaksanaan penggunaan Make a match dengan kartu soal. 
Hasil tes siklus II menunjukkan bahwa rata-rata hasil belajar ranah kognitif siswa dalam Pelajaran PAI dapat dilihat pada tabel nilai hasil belajar siswa siklus II sebagai berikut:

Tabel 2. Nilai Tes Siswa Siklus II

\begin{tabular}{|c|c|c|c|c|c|}
\hline \multirow{2}{*}{ No } & \multirow{2}{*}{ Nama Siswa } & \multirow{2}{*}{ KKM } & \multirow{2}{*}{ Nilai } & \multicolumn{2}{|c|}{ Keterangan } \\
\hline & & & & Tuntas & Tidak Tuntas \\
\hline 1 & Aulia Nurlina & 78 & 90 & Tuntas & \\
\hline 2 & Arfiana Dewi & 78 & 85 & Tuntas & \\
\hline 3 & Abigail Imam W & 78 & 85 & Tuntas & \\
\hline 4 & Ezha Artha N & 78 & 85 & Tuntas & \\
\hline 5 & Fidyah Mauriani & 78 & 80 & Tuntas & \\
\hline 6 & Fahlita Mulyanti & 78 & 82 & Tuntas & \\
\hline 7 & Iqbal Eka Satria & 78 & 80 & Tuntas & \\
\hline 8 & Karin Ramadhani & 78 & 75 & & Tidak Tuntas \\
\hline 9 & Kirana A & 78 & 85 & Tuntas & \\
\hline 10 & Saiban & 78 & 85 & Tuntas & \\
\hline 11 & Nur Huda & 78 & 85 & Tuntas & \\
\hline 12 & M. Ridho & 78 & 85 & Tuntas & \\
\hline 13 & Nazwa Salsabilah & 78 & 80 & Tuntas & \\
\hline 14 & Tegar & 78 & 85 & Tuntas & \\
\hline 15 & Nur Fadilah & 78 & 80 & Tuntas & \\
\hline 16 & Nikita & 78 & 85 & Tuntas & \\
\hline 17 & Putri Firda & 78 & 85 & Tuntas & \\
\hline 18 & Reksa Satya & 78 & 85 & Tuntas & \\
\hline 19 & Rizky Aqila & 78 & 80 & Tuntas & \\
\hline 20 & Ridho Ahmad & 78 & 70 & & Tidak Tuntas \\
\hline & Jumlah & & 1575 & 18 & 2 \\
\hline & Rata-rata & & 78,75 & & \\
\hline & osentase Ketuntasan (\%) & & & 90 & 10 \\
\hline & Nilai Tertinggi & & 90 & & \\
\hline & Nilai Terendah & & 60 & & \\
\hline
\end{tabular}

Berdasarkan tabel 2. tentang hasil penelitian siklus II, ketuntasan belajar siswa pada siklus II dapat digambarkan pada grafik sebagai berikut:

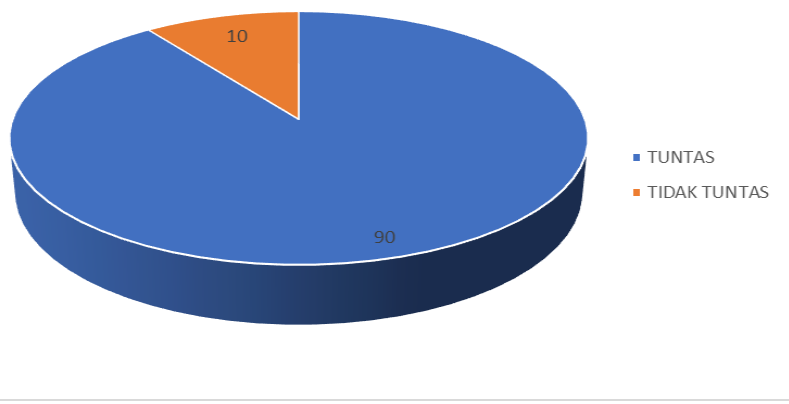

Grafik 3 Grafik ketuntasan Belajar Siswa Siklus II Pembahasan 
Setelah memperbaiki kegiatan pembelajaran yang ada di siklus 1 maka pelaksanaan pada siklus 2 sudah membuat rancangan yang lebih baik sehingga mengalami kemajuan dan peningkatan. Adapun perolehan nilai evaluasi pada siklus 1 yang dibandingkan dengan perolehan nilai evaluasi siklus 2, dapat dilihat pada tabel di bawah ini :

Tabel 4. Perolehan Nilai Evaluasi Siklus I dan Siklus II

\begin{tabular}{|c|c|c|c|}
\hline \multirow{2}{*}{ No } & \multirow{2}{*}{ Nama Siswa } & \multicolumn{2}{|c|}{ Nilai } \\
\hline & & Siklus I & Siklus II \\
\hline 1 & Aulia Nurlina & 85 & 90 \\
\hline 2 & Arfiana Dewi & 80 & 85 \\
\hline 3 & Abigail Imam W & 78 & 85 \\
\hline 4 & Ezha Artha N & 78 & 85 \\
\hline 5 & Fidyah Mauriani & 80 & 80 \\
\hline 6 & Fahlita Mulyanti & 78 & 82 \\
\hline 7 & Iqbal Eka Satria & 80 & 80 \\
\hline 8 & Karin Ramadhani & 60 & 75 \\
\hline 9 & Kirana A & 80 & 85 \\
\hline 10 & Saiban & 80 & 85 \\
\hline 11 & M. Rayyan Syafieq & 80 & 85 \\
\hline 12 & M. Ridho & 80 & 85 \\
\hline 13 & Nazwa Salsabilah & 65 & 80 \\
\hline 14 & Tegar & 80 & 85 \\
\hline 15 & Nur Fadilah & 65 & 80 \\
\hline 16 & Nikita & 82 & 85 \\
\hline 17 & Putri Firda & 65 & 85 \\
\hline 18 & Reksa Satya & 80 & 85 \\
\hline 19 & Rizky Aqila & 82 & 80 \\
\hline 20 & Ridho Ahmad & 65 & 70 \\
\hline & Jumlah & 1497 & 1575 \\
\hline & Rata-rata & 76,15 & 78,75 \\
\hline & Prosentase Ketuntasan (\%) & 75 & 90 \\
\hline & Nilai Tertinggi & 85 & 85 \\
\hline & Nilai Terendah & 65 & 65 \\
\hline
\end{tabular}

Berdasarkan tabel 4 perbandingan peroleh nilai siswa siklus I dan siklus II dapat digambarkan pada grafik sebagai berikut 


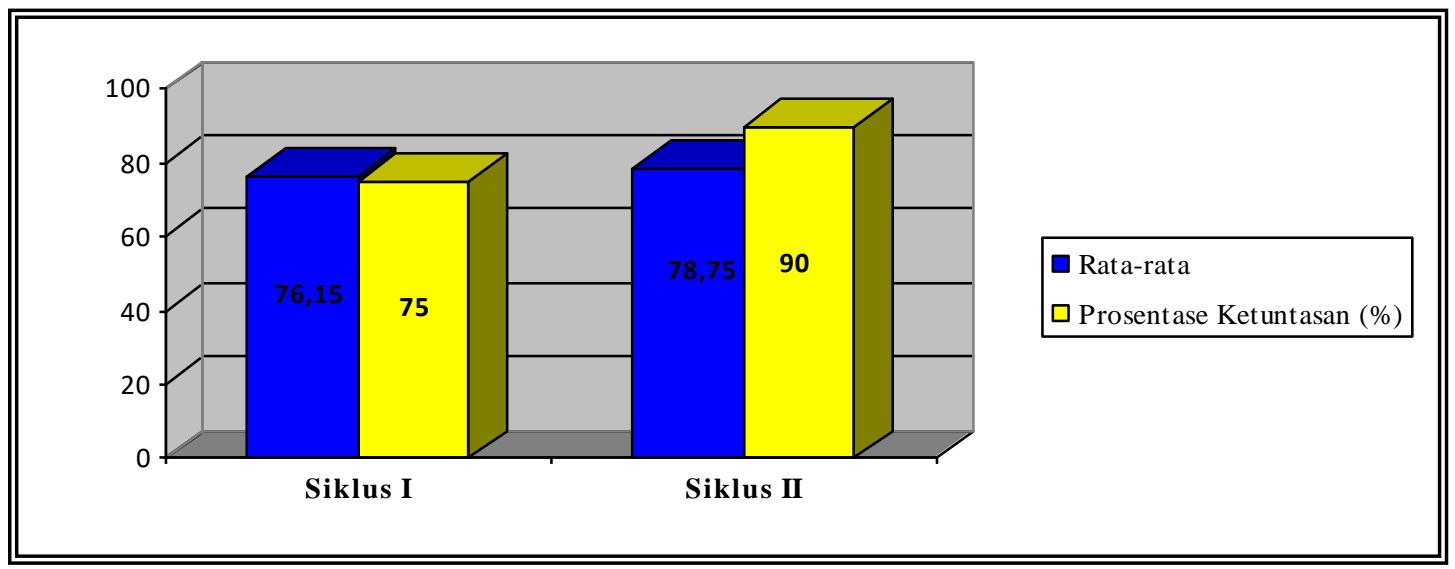

Gambar 4. Grafik Perolehan Nilai Evaluasi pada Siklus 1 dan 2

Berdasarkan grafik batang diatas terlihat peningkatan hasil belajar siswa baik dari rata-rata klasikal maupun porsentase ketuntasan belajar terlihat nilai rata-rata pada siklus I 76,15 meningkat menjadi 78,75 pada siklus II begitupun dengan porsentase ketuntasan belajar terlihat pada grafik siswa yang tuntas pada siklus I $75 \%$ meningkat menjadi $90 \%$ pada siklus II. Berdasarkan hasil penelitian secara keseluruhan menunjukan terjadi peningkatan hasil belajar siswa dari sebelum dilaksanakan tindakan perbaikan pembelajaran ke siklus I sampai dengan siklus II. Hal ini sesuai dengan hasil analisis metode pembelajaran yang dilakukan oleh Soedomo,1990 (dalam Puger : 2004) yang menyatakan bahwa metode pembelajaran yang diterapkan oleh seorang guru berpengaruh terhadap hasil belajarnya.

Adapun perbandingan perolehan nilai evaluasi mulai dari sebelum tindakan perbaikan, siklus 1, siklus 2 dapat dilihat dari tabel di bawah ini.

Tabel 5. Rekapitulasi Perolehan Nilai Nilai Pra Siklus, Siklus I dan Siklus II

\begin{tabular}{|c|c|c|c|c|}
\hline \multirow{2}{*}{ No } & \multirow{2}{*}{ Nama Siswa } & \multicolumn{3}{|c|}{ Nilai } \\
\cline { 2 - 4 } & & Pra Siklus & Siklus I & Siklus II \\
\hline 1 & Aulia Nurlina & 80 & 85 & 90 \\
3 & Arfiana Dewi & 75 & 80 & 85 \\
4 & Abigail Imam W & 65 & 78 & 85 \\
5 & Ezha Artha N & 65 & 78 & 85 \\
6 & Fidyah Mauriani & 65 & 80 & 80 \\
7 & Fahlita Mulyanti & 72 & 78 & 82 \\
8 & Iqbal Eka Satria & 70 & 80 & 80 \\
9 & Karin Ramadhani & 65 & 80 & 85 \\
10 & Kirana A & 55 & 60 & 75 \\
11 & Saiban & 65 & 80 & 85 \\
12 & M. Rayyan Syafieq & 70 & 80 & 85 \\
13 & M. Ridho & 65 & 80 & 85 \\
14 & Nazwa Salsabilah & 60 & 65 & 80 \\
15 & Tegar & 65 & 80 & 85 \\
16 & Nur Fadilah & 60 & 65 & 80 \\
17 & Nikita & 75 & 82 & 85 \\
\hline
\end{tabular}


Vol 1. No. 3, Juli 2021 P-ISSN : 2774-8014, e-ISSN : 2774-7034

\begin{tabular}{|c|c|c|c|c|}
\hline 18 & Reksa Satya & 65 & 80 & 85 \\
19 & Rizky Aqila & 70 & 82 & 80 \\
20 & Ridho Ahmad & 50 & 65 & 70 \\
\hline \multicolumn{2}{|c|}{ Jumlah } & 1392 & 1523 & 1575 \\
\hline & Rata-rata & 66,29 & 76,15 & 78,75 \\
\hline \multicolumn{2}{|c|}{ Prosentase Ketuntasan (\%) } & 38,10 & 75 & 90 \\
\hline Nilai Tertinggi & 80 & 85 & 90 \\
\hline Nilai Terendah & 55 & 65 & 70 \\
\hline
\end{tabular}

Secara keseluruhan nilai rata-rata siklus 1 dan 2 sudah menunjukan keberhasilan dari penggunaan Make a match dengan kartu soal dalam meningkatkan hasil belajar PAI tentang mengenal malaikat dan tugasnya pada siswa kelas IV SDN 029 Balikpapan Tengah dengan ketuntasan belajar mencapai $90, \%$ atau hanya 2 siswa yang belum tuntas dari 20 orang siswa, walaupun masih terdapat 2 siswa yang tidak tuntas pada penelitian ini dianggap sudah mencapai kriteria keberhasilan yaitu secara klasikal $85 \%$ siswa tuntas dalam pembelajaran, secara terperinci tergambar pada grafik-grafik sebagai berikut

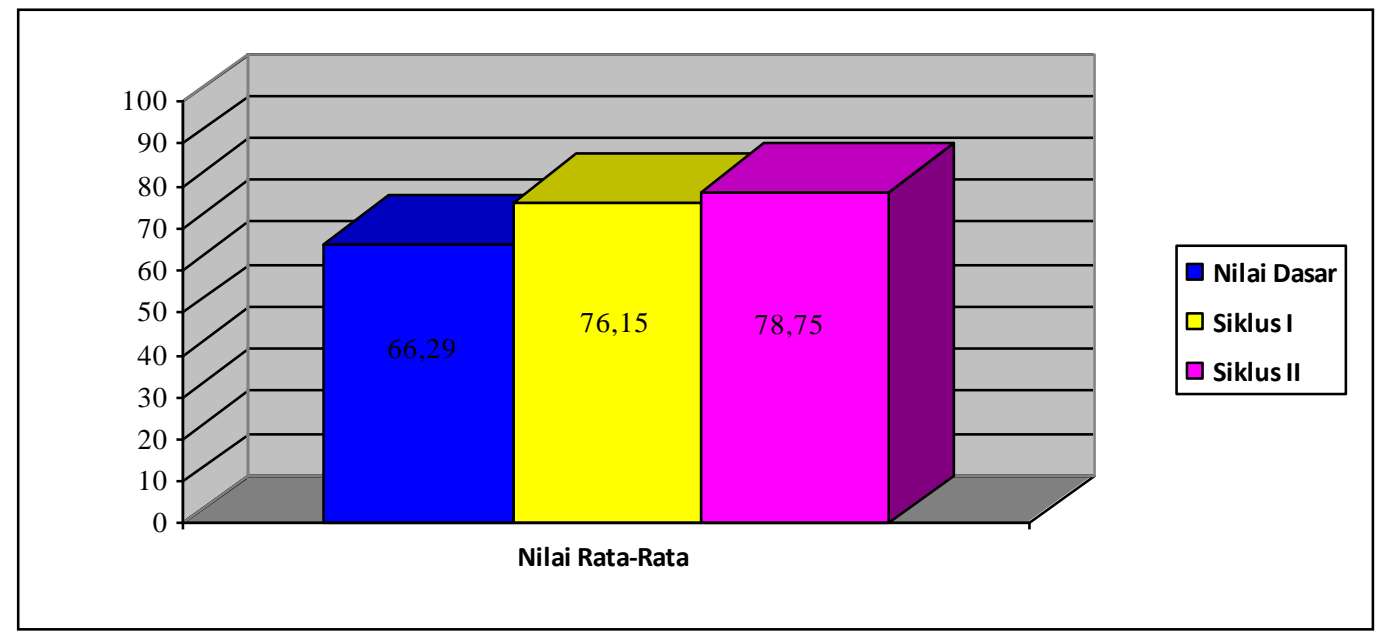

\section{Grafik 5. Grafik Perolehan Nilai Evaluasi Nilai pra siklus, Siklus I, dan Siklus II}

Ketuntasan Hasil belajar siswa secara keseluruhan selama melaksanakan tindakan penelitian perbaikan hasil belajar PAI pada pokok mengenal malaikat dan tugasnya pada siswa kelas IV SDN 029 Balipapan Tengah dapat terlihat pada gambar grafik sebagai berikut

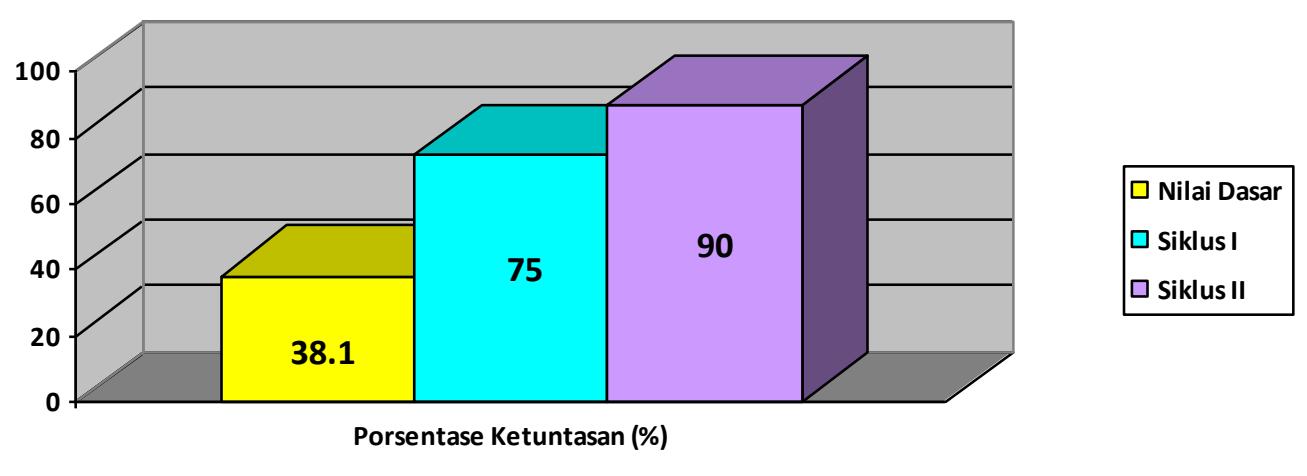

Grafik 6. Grafik Persentase Pencapaian Kkm Nilai Pra Siklus, Siklus I, dan Siklus Ii 


\section{PENUTUP}

Berdasarkan hasil penelitian perbaikan pembelajaran yang telah dilaksanakan dapat disimpulkan bahwa pembelajaran dengan mengunakan Make a match dengan kartu soal dapat meningkatkan hasil belajar PAI tentang mengenal malaikat dan tugasnya pada siswa kelas IV SDN 029 Balikpapan Tengah Tahun Pelajaran 2019/2020. Peningkatan tersebut dapat dilihat pada setiap siklusnya, yaitu nilai rata-rata sebelum tindakan perbaikan pembelajaran dengan dengan rata-rata 66,29 meningkat menjadi 76,15 pada siklus I dan pada siklus II meningkat menjadi 78,75 sedangkan peningkatan ketuntasan belajar siswa mengalami peningkatan secara signifikan yaitu ketuntasan sebelum adanya tindakan perbaikan pembelajaran yaitu siswa yang tuntas hanya $38,10 \%$ meningkat menjadi $75 \%$ pada siklus I kemudian pada siklus II meningkat menjadi $90 \%$. Dengan hasil penelitian ini penulis memberikan saran kepada guru kelas agar selalu menggunakan media dalam membantu proses pembelajaran, terutama pada mata pelajaran yang bersifat abstrak seperti pada pelajaran PAI materi mengenal malaikat dan tugasnya. Diharapkan guru selalu menyajikan proses pelaksanaan pembelajaran yang menyenangkan dengan bantuan media sebagai alat bantu dalam proses mengajar. Dan Guru harus selalu berinovatif dalam menyediakan media-media pembelajaran. Terutama pada mata pelajaran PAI .

\section{DAFTAR PUSTAKA}

Arikunto ( 2003) Dasar-Dasar Evaluasi Pendidikan, edisi revisi, Bumi Aksara, Yogyakarta Arikunto, Suharsimi., Suhardjono, Supardi. (2006). Penelitian Tindakan Kelas. Jakarta: PT Bumi Aksara

Departemen Pendidikan Nasional. (2003). Undang-Undang Republik Indonesia, Nomor 20 Tahun 2003 Tentang Sistim Pendidikan Nasional Depdiknas RI : Jakarta

Depdiknas, (2002b). Pedoman Khusus Sistem Pengujian Hasil KBM Berbasis Kemampuan Dasar.Dirjen Dikdasmen.

Depdiknas. (2004) Kerangka Dasar Kurikulum 2004. Jakarta Departemen Pendidikan Nasional (2006)

Djamarah, Saiful Bahri, 2006. Strategi Belajar Mengajar. Jakarta : PT Rineka Cipta

Leo Sutrisno (2008:25) Pengembangan Pembelajaran SD. Jakarta : Dirjen Dikti Depdiknas.

Hamalik Oemar (2002) Pendidikan Guru Berdasarkan Pendekatan Kompetensi. Jakarta : Bumi Aksara

Puger, I Gusti Ngurah. (2004). Belajar Kooperatif. Diktat Perkuliahan Mahasiswa Unipas.

Zuhairini, dkk. Metodik Khusus Pendidikan Agama Islam, Surabaya, Usaha Nasional, 1983. hlm:79 